\title{
EFFECTIVENESS OF ETHANOL EXTRACT AND ETHYL ACETATE FRACTION OF ARECA NUT (ARECA CATECHU L.) ON THE IL-18 SERUM CYTOKINE LEVEL IN MICE (MUS MUSCULUS) INFECTED WITH TRICHURIS MURIS EGG
}

\author{
Endy Juli Anto'), Aznan Lelo²), Syafruddin Ilyas'3) \\ 1)Department of Parasitology, Faculty of Medicine, Universitas Methodist Indonesia \\ 2)Department of Pharmacology, Faculty of Medicine, Universitas Sumatera Utara \\ 3)Department of Biology, Faculty of Mathematics and Physical Sciences, \\ Universitas Sumatera Utara
}

\begin{abstract}
Background: Interleukin-18 is a protein which in humans is encoded by the IL-18 gene. The protein encoded by this gene is a proinflammatory cytokine. IL-18 promotes the development of chronic gastrointestinal helminth infection. There were some contradictory studies regarding the role of IL-18. In recent years, various studies have found natural and traditional ingredients for developing the alternative anthelmintic drugs, included areca nut (Areca catechu L.). This study aimed to examine the effectiveness of ethanol extract and ethyl acetate fraction of areca nut (Areca catechu L.) on the IL-18 serum cytokine level in mice (Mus musculus) infected with T. muris egg.

Subjects and Method: This was a quasi-experiment post-test only with control group design conducted at the Biology Laboratory, Faculty of Mathematics and Natural Sciences, University of North Sumatra, from September 2018 to July 2019. A sample of 70 mice was divided into 7 groups: (1) 10 mice in negative control group not infected with T. muris eggs; (2) 10 mice in positive control group infected with 200 T.muris eggs; (3) 10 mice in intervention group (I1) infected with T. muris eggs received $100 \mathrm{mg} / \mathrm{kgBW}$ areca nut ethanol extract p.o.; (4) 10 mice in intervention group (I2) infected with T. muris eggs received $150 \mathrm{mg} / \mathrm{kg}$ wt areca nut ethanol extract p.o; (5) 10 mice in intervention group (I3) infected with T. muris eggs received $100 \mathrm{mg} / \mathrm{kg}$ wt ethyl acetate fraction of areca nut p.o; (6) 10 mice in intervention group (I4) infected with $T$. muris eggs received $150 \mathrm{mg} / \mathrm{kgBW}$ ethyl acetate fraction of areca nut p.o; and (7) 10 mice in intervention group (I5) infected with $T$. muris eggs received $1 \mathrm{mg} /$ BWAlbendazole p.o. The mean differences between groups were tested by One Way ANOVA.

Results: The means of IL-18 serum cytokine level in all 7 groups as follows: (1) Negative control group $($ Mean= 75.22; $\mathrm{SD}=35.06)$; (2) Positive control group $(\mathrm{Mean}=57.66 ; \mathrm{SD}=$ 13.40); (3) I1 group with $100 \mathrm{mg} / \mathrm{kgBWareca}$ nut ethanol extract (Mean=64.24; $\mathrm{SD}=$ 24.68); (4) I2 group receieving $150 \mathrm{mg} / \mathrm{kgBW}$ areca nut ethanol extract (Mean= 71.64; $\mathrm{SD}=35.50$ ); (5) I3 group with (Mean=63.77; $\mathrm{SD}=41.13$ ); (6) I4 group with $150 \mathrm{mg} / \mathrm{kgBW}$ ethyl acetate fraction of areca nut (Mean= 74.98; $\mathrm{SD}=42.27)$; and (7) I5 group with 1 $\mathrm{mg} / \mathrm{kgBW}$ Albendazole (Mean=70.72; $\mathrm{SD}=12.98)$. The mean differences between groups were statistically non-significant $(\mathrm{p}=0.899)$.

Conclusion: The administration of ethanol extract or ethyl acetate fraction of areca nut (Areca catechu L.) is not effective in changing the IL-18 serum cytokine level in mice (Mus musculus) infected with Trichuris muris egg.
\end{abstract}

Keywords: Areca catechu L., IL-18, Mus musculus, Trichuris muris, mice

\section{Correspondence:}

Endy Juli Anto. Faculty of Medicine, Universitas Methodist Indonesia, Medan, Sumatera Utara. Email: dr.endyjulianto86@gmail.com. Mobile: +6282367667575. 